
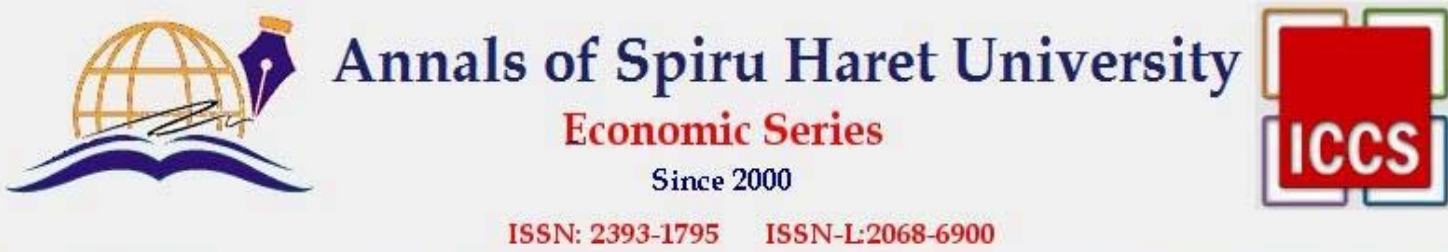

Issue 2/2016

\title{
THE ROLE OF PUBLIC DIPLOMACY IN INTERNATIONAL RELATIONS IN FULL PROCESS OF GLOBALIZATION
}

\author{
Elena GURGU, Aristide Dumitru COCIUBAN \\ “Spiru Haret” University, Ion Ghica Street, no. 13, Bucharest, 030045, \\ Romania, Tel.: +40214551000, Fax: +40213143900, \\ Email: elenagurgu@yahoo.com,tedy_cociuban@yahoo.com
}

\begin{abstract}
The purpose of this article was to highlight the role of public diplomacy in linking countries of the world in the process of economic globalization. Like objectives we intend to emphasize the kinds of powers that play an important role in public diplomacy and national policies on public diplomacy. The investigations carried out by us so far show that contemporary international relations recorded, under the impact of globalization, a process of resizing, which leads to the removal of the state monopoly on foreign policy. As a result, a whole range of non-state actors influence the image of a country abroad and information technologies gives them multiple communication mechanisms. In this situation, diplomatic activities must be accompanied by a process of communication, both in its internal and foreign markets.
\end{abstract}

Key words: public diplomacy; soft power; hard power; smart power; globalization; public policy; interstate relations.

JEL Classification: K2

\section{Introduction}

In this paper we wanted to emphasize the role public diplomacy has in relations between states in full process of globalization. The importance of studying this problem stems from the fact that more and more countries 

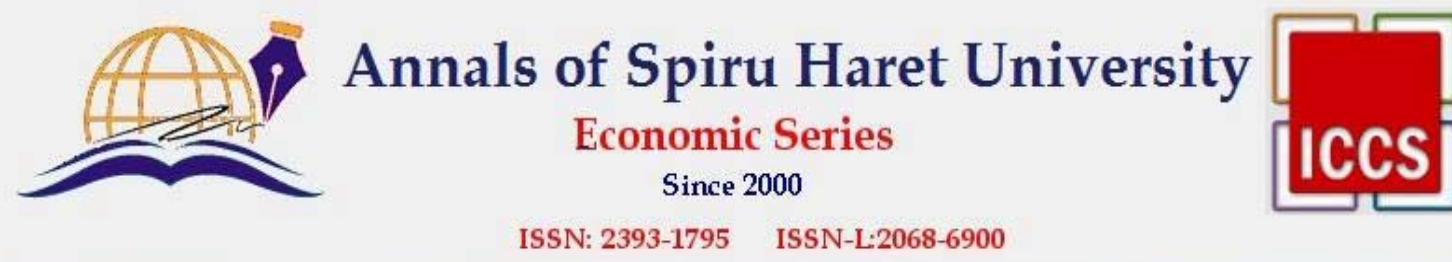

Issue $2 / 2016$

launching information campaigns in recent years aimed at contributing to the priorities of foreign policy, but also to obtain their support for these companies. In the context of participatory democracy, public opinion adherence to government policy is indispensable for the survival of a government and that is why we, the authors, try to familiarize the general public with useful terms of public diplomacy and the ways in which public diplomacy can achieve. External strategies to amend or strengthen international public perception to a particular country are also part of their public relations campaigns.

In international relations, the term "public diplomacy" appeared to describe aspects of international relations, which manifests itself outside the interaction between state structures. There are actions that we attribute to public diplomacy and existed from ancient times. Leaders of Rome, for example, invited the boys of neighbouring countries to do their studies in Rome. This is an example of public diplomacy. In what follows we will discover public diplomacy as it is seen by specialists in the field.

\section{About Public Diplomacy in Literature}

The term "public diplomacy" was introduced into scientific circulation in 1965, when Edmund Gullion, a career diplomat and dean of the School of Law and Diplomacy of Tufts University, created the Centre for Public Diplomacy Edward R. Murrow. The informational material of the Centre described this term of public diplomacy as "the influence of public attitudes in the formation and execution of foreign policies. It encompasses dimensions of international relations beyond traditional diplomacy ... [including]:

- formation by governments of public opinion in other countries;

- interaction between private interest groups from different countries;

- informing people about international affairs and their influence on domestic policy;

- communication between those whose function is communication, such as diplomats and foreign journalists;

-(and) the process of intercultural communication." [Dizard, 2001] 

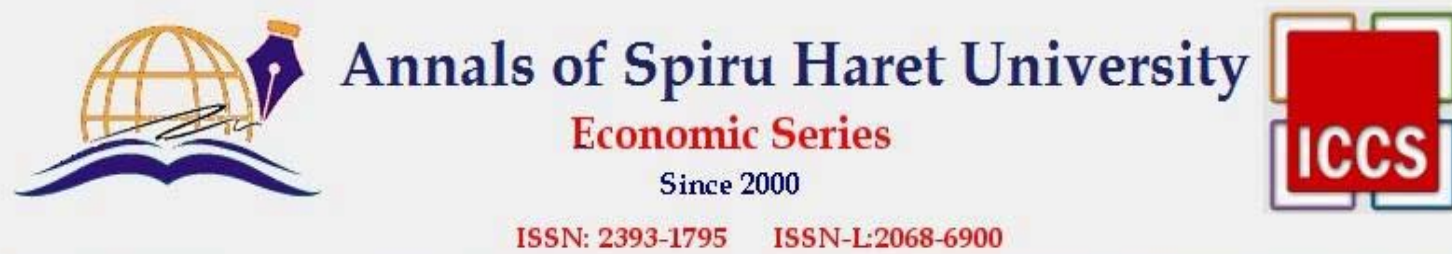

Issue 2/2016

The term became shortly dominating US government, providing the theoretical foundation necessary to external activity of the Agency of American Intelligence - USIA (US Information Agency - United States Information Agency) that handled between 1953 and 1999 the dissemination of information and broadcast media US official, taking over the role that Voice of America had it since the time of the Second World War. Because the activities of this agency were defined in public opinion basically as propaganda, a term that had acquired negative connotations, USIA accepted the term of "public diplomacy" as descriptor of its official activity. The US State Department defines public diplomacy as US government-funded programs designed to inform or influence public opinion abroad [Wolf \& Rosen, 2004].

In the same vein, Hans Tuch defines public diplomacy as a communication process of the government of a country with foreign audiences, trying to explain his ideas and ideals of respective nation, its institutions and its culture as well as national interests and policies [Tuch, 2010]. Hans Tuch also defined public diplomacy as "official government efforts to train abroad communication environment in which US foreign policy is conducted in order to reduce the degree to which misconceptions and errors of perception complicate relations between the U.S. and other nations." [Tuch, 2010] Objectives and national interests are disclosed to a foreign public through a variety of means, including international programs, cultivating journalists and foreign academics, cultural and educational exchanges, visits and conferences scheduled, and also publications.

Griffin Malone expands the definition including the need to understand others as fundamental to the success of public diplomacy: "if we want to have success in our efforts to create understanding for our society and for our policies, first of all we must understand the leitmotifs, the culture, the history and the psychology of peoples with whom we want to communicate, and certainly their language."

Former diplomat John Brown describes US public diplomacy as " $a$ process involving three roles: information dissemination, education and cultural exchanges". 

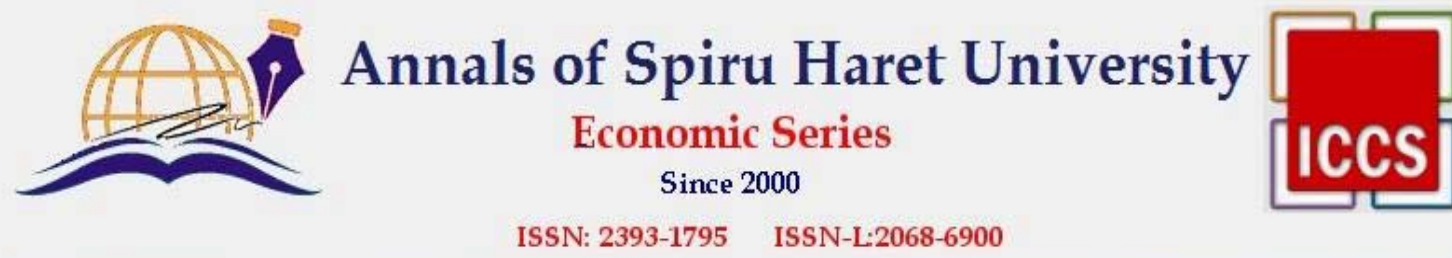

Issue 2/2016

Philip Taylor uses the term "perception management" to describe the informational role of public diplomacy in this regard by drawing a distinction between public affairs, public interest, psychological operations, media management and public diplomacy.

Researchers in the field of cultural diplomacy, as Kevin Mulcahy and Harv Feigenbaum emphasize the difference between public and cultural diplomacy in that public diplomacy is moving towards disseminating information and promoting policies in the short term, and the cultural diplomacy is establishing long-term relationships.

Public diplomacy, as perceived traditionally, includes:

- governmental support of the programs in the cultural, educational and informational domains;

- exchanges of citizens;

- programs oriented towards informing and influencing foreign audiences.

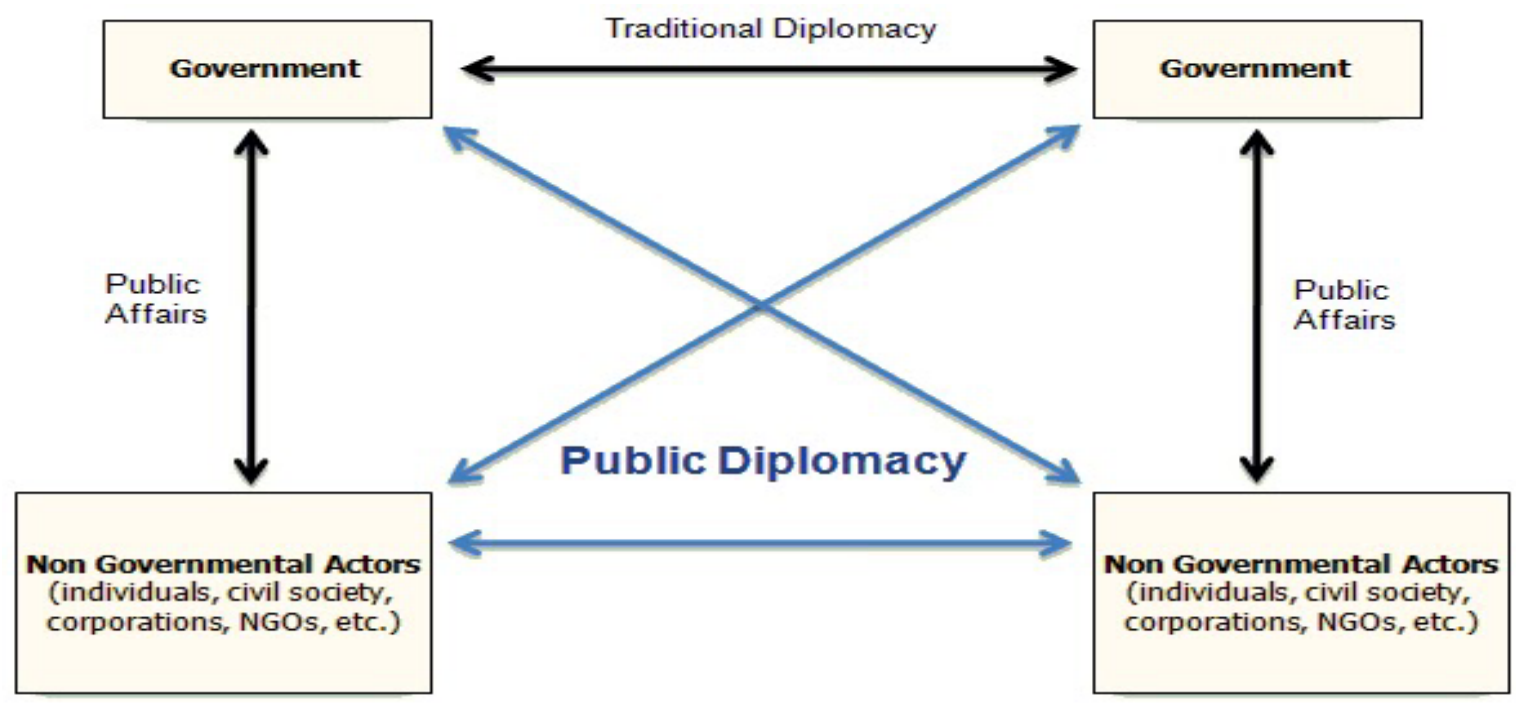

Figure no. 1. Traditional diplomacy vs. public diplomacy

Source: after a figure realized by Kevin Mulcahy and Harv Feigenbaum

From the Report of US Commission on Public Diplomacy "we conclude that this is an open exchange of ideas and information, is an inherent characteristic of democratic societies. Its mission is essential to global and foreign policy, being indispensable to [national] interests, ideals and leadership in the world"' [Commission's Report on Public Diplomacy, 1991] 

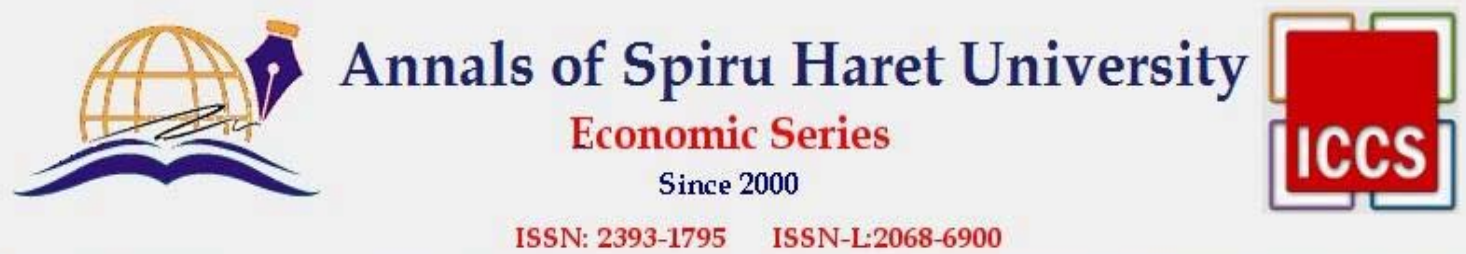

Issue 2/2016

US Congressman Henry Hyde believes that "the role set for our public diplomacy [is] to recruit people of the world in a common cause and to convince them that the objectives towards which tend themselves freedom, security and prosperity - are the same ones United States tend to promote abroad" [Nye, 2005].

The Strategy Council of Great Britain for Public Diplomacy define this notion as "activity that seeks to influence positively, including by creating relationships and partnerships, perceptions of individuals and organizations abroad about the United Kingdom" [Leonard, Stead and Smewing, 2002].

\section{Hard Power and Smart Power Type of Public Diplomacy vs. Propaganda}

Political scientist Joseph Nye [Nye, 2004] describes public diplomacy as a political expression of soft power concept which he introduced in the early 90. In international politics, power is the ability of an actor to influence another to perform certain actions which would not otherwise be undertaken. So, hard power is the ability of an actor to compel another to perform certain actions and tactics that include military intervention, coercive diplomacy and economic sanctions. In contrast, soft power refers to the ability to convince the actor to take those actions. The combination of the two is the power of smart, an approach that strategically uses the most appropriate tactics of the two aforementioned dimensions of power.

So, the concept of "public diplomacy" is part of soft power, which, as defined by Joseph Nye, is the ability to achieve the expected goal based on voluntary participation by allies, not by constraint. [Nye, 2004] Soft power lies in culture and political ideals of the country. "When you manage to make others admire your ideals and want what you want... Seduction is always more effective than coercion, and many values such as democracy, human rights and individual opportunities are deeply attractive" [Bator, 2005]. 


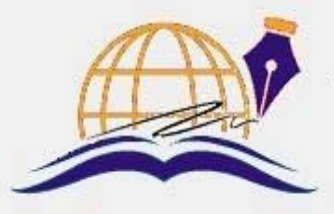

Annals of Spiru Haret University

Economic Series

Since 2000

ISSN: 2393-1795 ISSN-L:2068-6900

\section{Issue 2/2016}

\section{Table no. 1. The differences between types of power in public diplomacy}

The Types of Power:

\begin{tabular}{|l|l|l|}
\hline Type of Power & Mechanism & Illustration \\
\hline Hard Power & Coercion & $\begin{array}{l}\text { Country B does what Country A wants } \\
\text { because Country A would harm B if it } \\
\text { does not comply }\end{array}$ \\
\hline Economic Power & Incentive & $\begin{array}{l}\text { Country B does what Country A wants } \\
\text { because Country A will reward Country } \\
\text { B for complying }\end{array}$ \\
\hline Soft Power & Co-Option & $\begin{array}{l}\text { Country B does what Country A wants } \\
\text { because B is convinced that what A } \\
\text { wants is best. }\end{array}$ \\
\hline
\end{tabular}

Source: Nye, Joseph S., “The Benefits of Soft Power”, Compass: A Journal of Leadership, (Spring 2004-4)
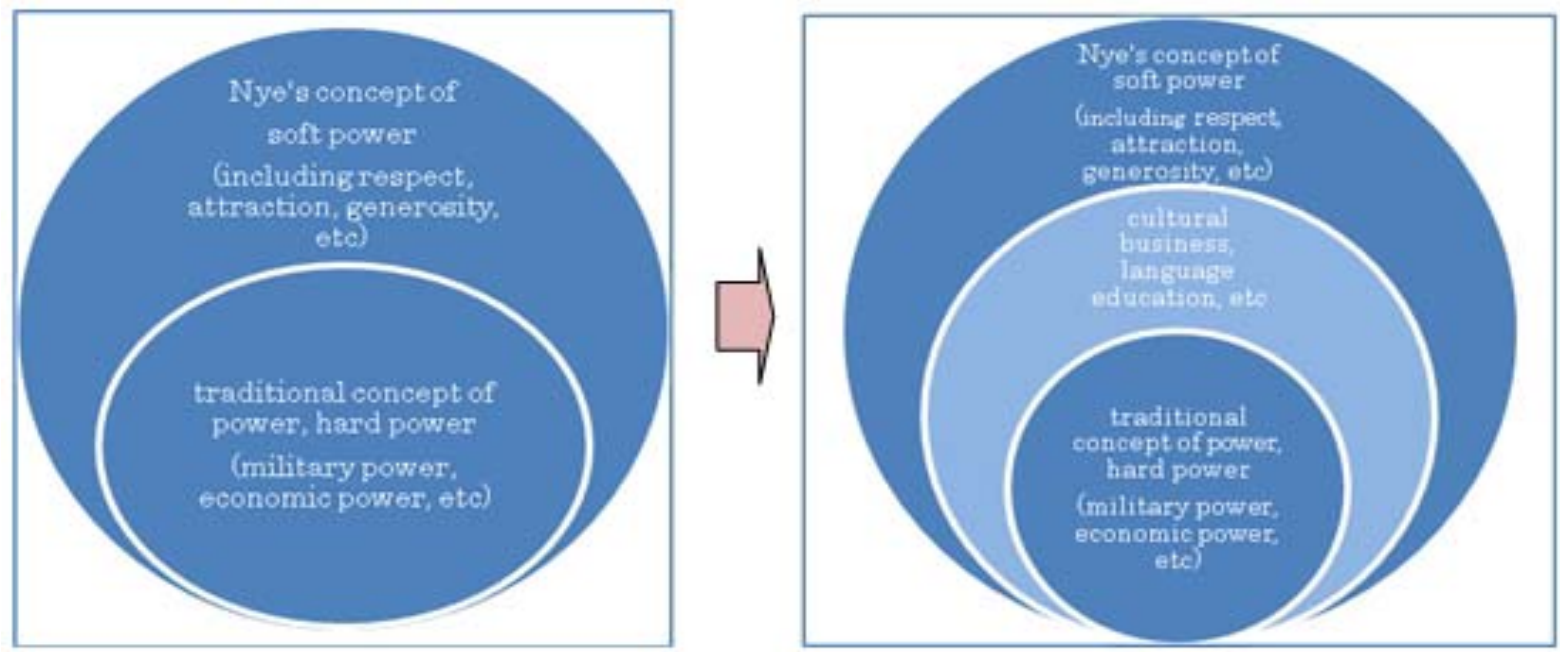

Figure no. 2. Nye's concept of soft power in public diplomacy

Source: after a figure realized by Jozef Bator, 2005 

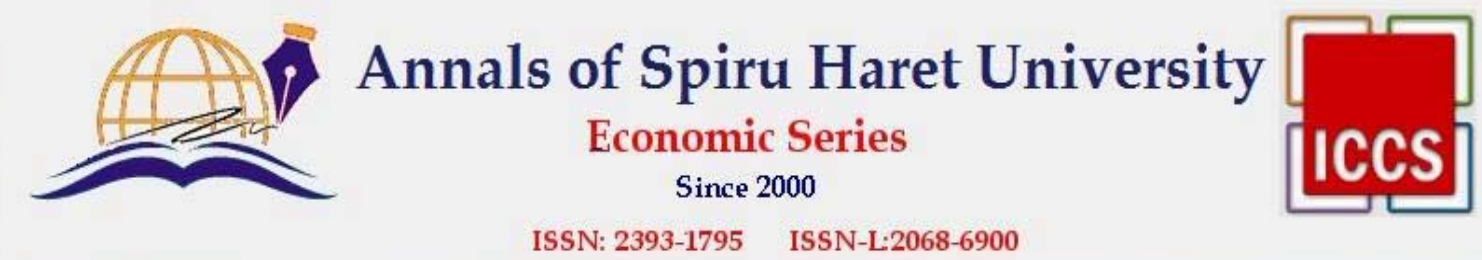

Issue 2/2016

Soft power of a country is created through the activities of multiple actors and organizations impacting foreign audience - artists, art galleries and music television, NGOs, political parties, writers and artists' associations, journalists and media groups, researchers and teachers, entrepreneurs and religious leaders etc. [Melissen, 2005].

Introducing the use of this term was necessary because the activities involved were assigned to a concept that had already managed to manifest negatively - propaganda. Attempts to define the two terms lie in the following: public diplomacy is based on known facts, real, while propaganda is based on a combination of counterfeits with the true facts.

We could identify some preconditions for the emergence of public diplomacy for governments and the scientific community:

- spread of democratic political regimes is characterized by continued pressure on political society, transforming the legitimacy of government policies in a key internal stability;

- growing role of multilateral framework in solving international problems determines the importance of persuading public opinion from other countries of the need to mobilize international coalitions;

- the establishment of information technologies era allows rapid movement of information, which leads to the emergence of a transnational public opinion;

- globalization offers states the opportunity to compete in order to attract foreign investment, trade opportunities, skilled workforce in order to ensure sustainable economic growth.

In this new conjuncture there isn't a clear delineation of internal policy subjects from the external once, since, for example, the political crisis in a country can destabilize the international situation.

In this context, public diplomacy has become an indispensable component of the foreign policy of states, but also a topic on the agenda of international organizations. In public discourse, the reference to the struggle for hearts and minds is encountered before, largely in British and American newspapers [Cull, 2010]. For example, in the London newspaper called Times, in January 1856 the term of "public diplomacy" was used to refer to the need to change the discourse of American President Franklin Pierce 

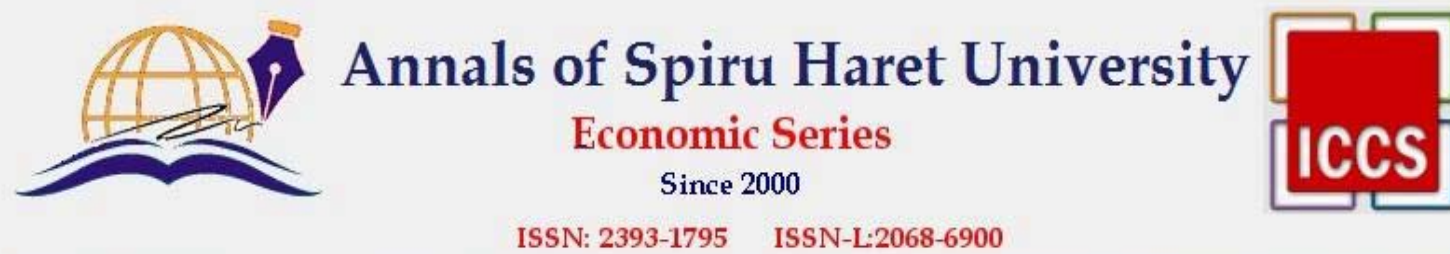

Issue 2/2016

towards Britain. During World War I, with reference to public diplomacy was used the term "open diplomacy", particularly in the context of the vision expressed by Woodrow Wilson on the international system.

Unlike official diplomacy, which could be described as the way in which states communicate with each other at different levels, public diplomacy focuses on how governments (or international organizations such as the United Nations), deliberately, through both officials and private persons or institutions communicate with citizens of other states [Guceac \& Porcescu, 2010]. The latter has a transparent character and involves a large number of players gathered around a common set of interests, opposed to official diplomacy, which is promoted by the relevant institutions. Although, as you know, communication with state's company, which is accredited, has always been a prerogative of the diplomats.

A precondition for carrying out an effective public diplomacy is the attractiveness of ideas and values promoted by a state within its own society. At present, most of the ideas about a country assimilated by foreign audiences are related to areas that cannot be under the strict supervision of state institutions - books, TV programs, films, national connotation products etc. In this case, the governments can only identify ways for positive messages, to reach target groups, although experience of government programs in this regard demonstrates many failures (e.g. information campaigns aimed at countries in the Middle East).

Originally, the term "public diplomacy" has been used as an antonym of propaganda. While propaganda is usually perceived as something evil, "public diplomacy" is based on the principle of "truthfulness", formulated by the former director of the US Agency for News, Edward Murrow, as follows: "The truth is most good propaganda and lies - the greatest evil. To be credible, we must be honest."

\section{What Isn't Public Diplomacy}

For a better understanding of the concept of public diplomacy, it is important to define what public diplomacy is not, by highlighting the differences from the two concepts with which it is often confused, namely propaganda and public relations. 


\section{Annals of Spiru Haret University \\ Economic Series \\ Since 2000 \\ ISSN: 2393-1795 \\ ISSN-L:2068-6900}

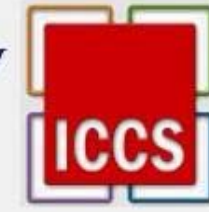

Issue $2 / 2016$

The Merriam-Webster dictionary defines propaganda as disseminating news, information or rumours with the aim to help or harm an institution, cause, or person. Another definition on the same dictionary is that propaganda represents ideas, facts or allegations issued deliberately to help the transmitter cause or to prejudice a case apart. Differences between propaganda and public diplomacy lie primarily from the intrinsic need of public diplomacy credibility and so the need to disseminate (as the originally role) information with highly truth indeed and with the function of listening and understanding attributed to public diplomacy later, function that is missing from propaganda.

Many researchers distinguish between public diplomacy and propaganda, based on the premise that propaganda by definition means deception and manipulation. "Lawyers" of public diplomacy argue that the most successful is to create a bond of trust between governments and nations through honest and open communication, based on the foreign policy objectives. It is irrefutable that the dialogue is also an important component of public diplomacy. This dialogue should not be perceived in one way, it is also essential to understand how the message is interpreted by various companies [Manheim, 2004]. It is important to emphasize that the difference between propaganda, public diplomacy and psychological operations is diluted with advancing a crisis (i.e., in terms of military action between the three "instruments" there is almost no difference). Thus, depending on the situation, either public diplomacy can be perceived as a means of propaganda or propaganda can become a means of public diplomacy.

Public relations of the foreign ministries, although using the same means and techniques such as public diplomacy, represent a communication with the citizens of the country transmitters in order to help in the understanding and interpretation of the outside world from a national perspective and to increase exposure of the international role of the respective country and its diplomatic service. The key difference here refers to the target audience of the exercise of communication, the public diplomacy being oriented in concept and definition by conviction and by hearing of external public. However, due to increased exposure of the 

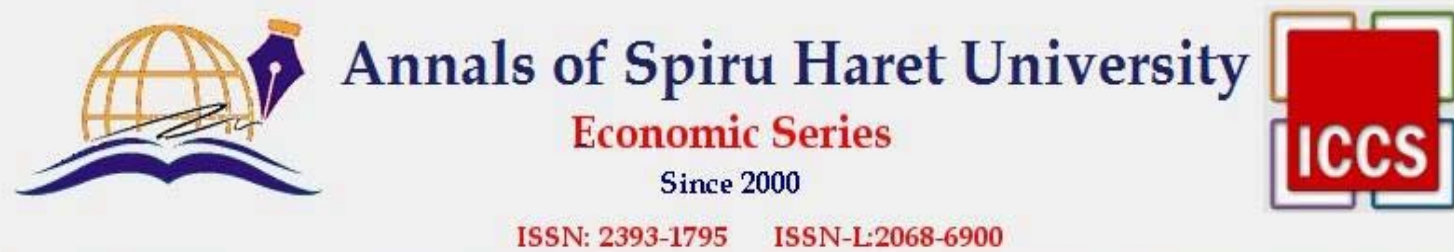

Issue 2/2016

media, the emergence of 24 hours cycles news, the Internet and other forms of revolution in communication lately, target audience of the two exercises have begun to lose its degree of ranks, domestic audiences becoming exposed to and influenced by official communications with external audiences, and vice versa.

Former US ambassador to Syria and Algeria, senior adviser to the State Department of Public Diplomacy, Christopher Ross, has identified seven 'pillars' or principles of public diplomacy [Ross, 2003].

1. Ensure understanding of foreign policy audience in the form that it is in reality, and not as others say or think [Ольга, 2006];

2. The need for policy explaining, demonstrating and justifying the rationality of its fundamental values;

3. Submission of consistent calls, truthful and convincing the international community;

4. Ability to adapt calls to the target audience, whose constituents are constantly studied;

5. Carrying out activities not only on narrow target segments, but also through mass media print and broadcast aimed at the broad masses;

6. Cooperation with various partners to include new representatives of the target audience;

7. Communication and active international exchange programs.

\section{National Policies in the Domain of Public Diplomacy}

There are opinions that the modern history of American public diplomacy began during the First World War, when the US government created the Committee on Public Information (known as Creep Committee) to ensure public support for US entering the war and to inform abroad about US efforts undertaken in support of democracy.

In 1948, American Congress passed the American Act of the informational and educational exchange as a legal basis for US foreign communication [Public Law 80-402 Smith-Mundt., 2004]. Is worth mentioning that through this document was introduced the prohibition to disseminate the programs of public diplomacy within the country. It also stipulated that the prepared material for international broadcast becomes 

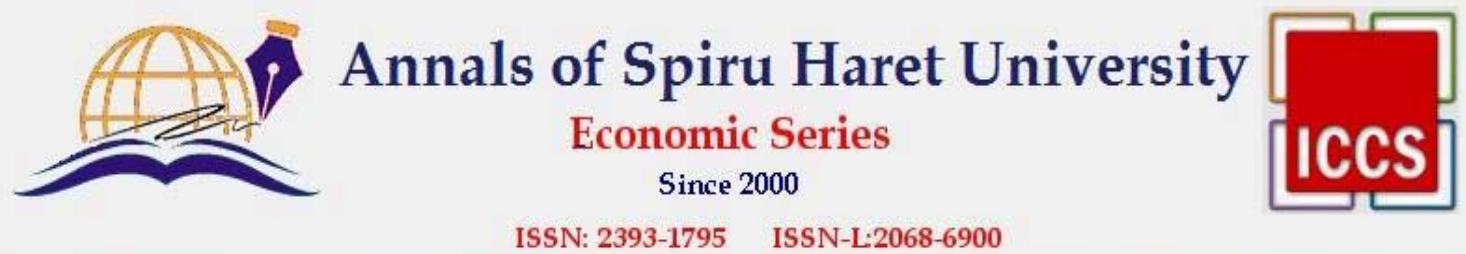

Issue 2/2016

available for local distribution only during the 12 years after initial creation or dissemination [Potter, 2005].

After the Cold War, the US has spread the opinion that public diplomacy is no longer necessary because the USSR, the main threat and the object of this activity, has disappeared. In 2000, the administration of President George W. Bush not only has allocated new resources for public diplomacy, but significantly expanded the staff involved in this process. After the terrorist attacks of 11 September 2001, officials in Washington have recast the foundations of American public diplomacy.

In the early 2000s, research has shown that Britain was associated by public opinion in many countries with some old outdated features: a country in decline, traditionalist, racist, imperial hue. In 2002, the British government created the Public Diplomacy Strategy Management Board in order to coordinate government activity in communication with the public abroad. Council approved a strategy in this area based on two concepts: dynamic and principled tradition and professionals [Leonard, Small \& Rose, 2005].

The EU accession process has led candidate countries to rethink their external image, while efforts are needed to convince their societies of the need to adopt European standards and fairness of the course taken. In the 2000-2004 period, the countries of Central and Eastern Europe have applied mechanisms of public diplomacy in parallel with negotiating EU accession treaties.

Ministry of Foreign Affairs of Poland conceived in this respect public diplomacy as all efforts of the state directed in order to influence public opinion abroad. The main actor of this is the government of a country and the container is the society of another country. Thus, public diplomacy is designed to complement formal diplomacy. In 2000, Poland launched its first public diplomacy campaign in order to influence the opinion of leaders and policy makers from the EU member states. [Ociepka \& Rzniejska, 2010] The campaign was anticipated by analyzing the public perception about Poland and poles in countries with the greatest influence on the future accession negotiation process, but also on Poland's position in the postaccession. Polish Framework Program, launched as a result, has defined two 

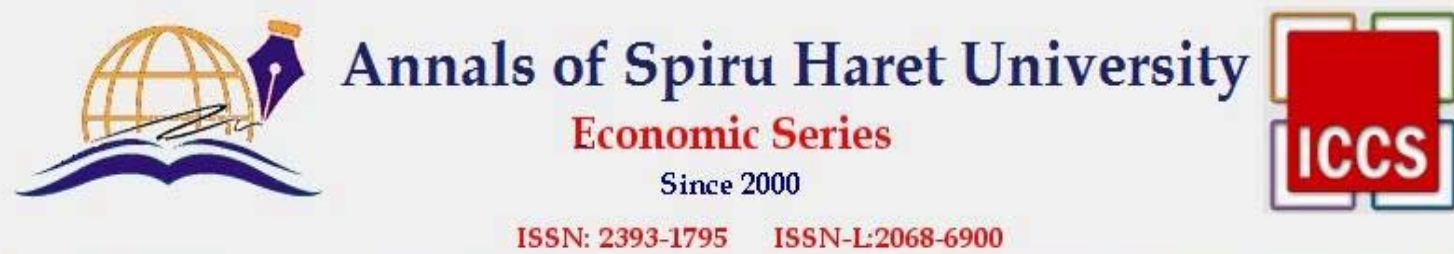

Issue $2 / 2016$

target groups: companies from the countries of "old" Europe - to support Poland's EU accession, and that a referendum vote for enlargement; the second group are opinion leaders and officials in those states which depended directly of accession. Thus, since in France dominates the stereotype of Polish underdeveloped agriculture, French officials and journalists in this country are presented in the visits namely achievements in this area. The same strategy was applied with other delegates, too: representatives of Austria and Germany were demonstrating achievements in the labour market and migration; those from Sweden were demonstrating efforts to curb pollution, etc. [Zorzoliu \& Gurgu, 2015].

Of course, the results of activities related to public diplomacy will never be known or anticipated to the end, because they depend on subjective factors or some unforeseen international events. It is widely believed that small and medium-sized states require a well-founded public diplomacy, since their perception abroad is characterized by a lack of information or the existence of preconceived stereotypes. Usually, these countries enter into international information flow only to the outbreak of crises or catastrophes. If in the case of large states, such as the US or China, public diplomacy is aimed at changing its image in the societies of other countries, for the smallest ones - to capture the attention of international public opinion.

\section{Conclusion}

In conclusion, today's public diplomacy is one of the most important concepts of political communication [Pigman, 2010].

We note that the literature about public diplomacy was written either by experts in diplomatic history [Jonsson \& Hall, 2005] or by practitioners of diplomacy. Both of them are attracted to the particular individual experience or sequence of events, instead of a generalization effort. The works of diplomacy practitioners have rather a prescriptive character, being dedicated to identifying best practices and analysis of some contexts that a future practitioner will be able to recognize in his work. Sometimes just to this kind of work was placed the label "diplomatic theory", although the authors emphasize, almost always, the discontinuity and change, on the way the world has changed between the time they started 

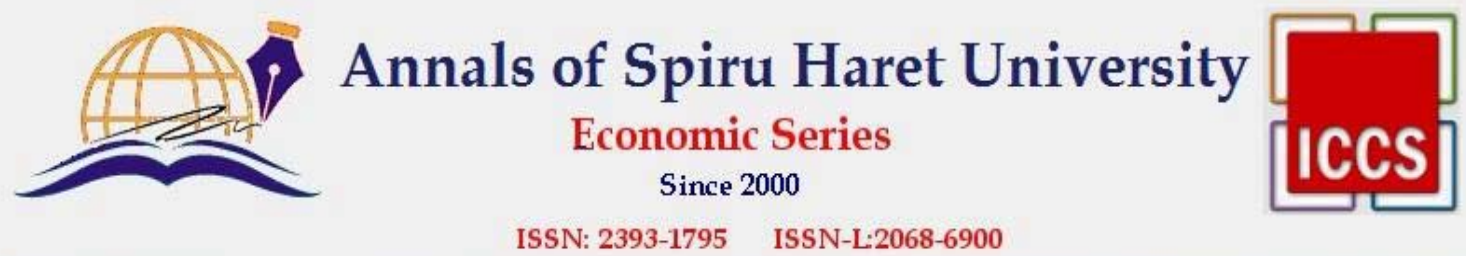

Issue 2/2016

their careers and the moment when they've done to it [Jonsson \& Hall, 2003]. But this rich literature is the very foundation on which to build a theory of diplomacy, through its connection with international relations theories. Of course, just as important is the crystallization of a theory about different eras of diplomacy history that allows us to extract similarities and differences.

An explanation, but not an excuse, of disconnection between diplomacy and international relations theories we find in the way it is conceptualized in international system, based on autonomous constituent entities (states).

International Relations Theory looks ahead "bottom-up" on the global political space, in which the society emerges from a natural posture and then it is theorized the way in which these companies interact between them [Thomson, 2005].

The state is the hierarchical political space, characterized by functional differentiation and specialization. On the other hand, the anarchic political space is populated with states and is characterized by the need for self-help, while the state has two tools: military force and diplomacy. Therefore, the nature of diplomacy is a tool that can be used in a quasivacuum space, governed by laws as "balance of power" or "self-help".

Building blocks of a theory about diplomacy will consist of processes that allow diplomacy to fulfil the role. The study on impact of the Knowledge Society upon diplomacy will return to the study of the impact on these processes. Despite the role that the Ministries of Foreign Affairs continue to play in developing recommendations and implementation of foreign policies, their authority was diminished considerably in relation to other ministries.

Academic field of international communication addresses the issue of information flows that are crossing the national border of the states and examines how the international system tries to regulate the development of communications infrastructure, and information flows. Traditionally, means of communication were used by leaders to achieve political and military objectives. But in the twentieth century, the international communication actors from the private sector have begun to play an increasingly important 

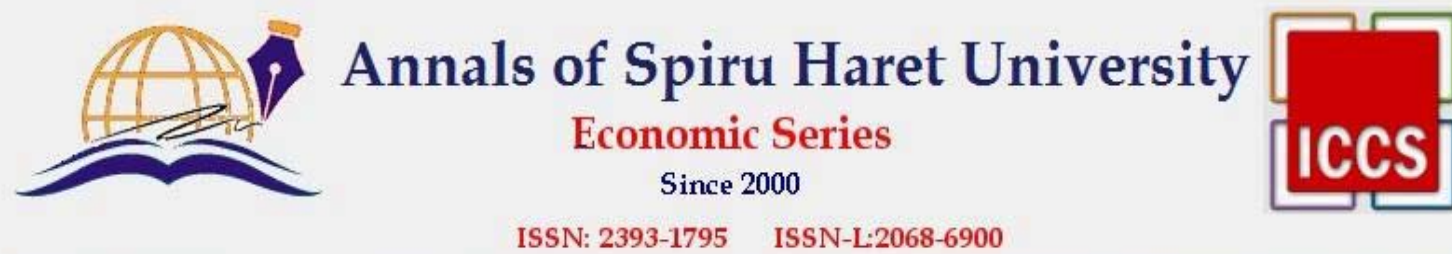

Issue $2 / 2016$

role, which led to the destruction of governments' monopoly on communication systems. Subsequently, technological development has created the conditions for the emergence of a new social force in international communication: transnational civil society.

It is the result of the fact that, Western states and international institutions that are strongly connected, such as: the European Union, World Bank, WTO and OECD, have reached a consensus on the scenario that will have in the future an Informational Society. The evolution is catalyzed by developing national and global information infrastructure, designed as a broadband transmission network through which large amounts of services and applications are offered in digital format, allowing alternative services worldwide. In this scenario, large monopolistic state-owned companies will be unable to collect the huge resources needed and will not be flexible enough to manage the benefits of changing technologies.

Most states have seen in communications market liberalization and in an effective competition on national level a precondition for the development of information infrastructures, while only France, Japan and South Korea have considered states' involvement in the development of optical network. As for applications and services, there was a perfect consensus: governments can serve only as a facilitator. [OECD, 1997]

The consequence has been the emergence of new types of institutional actors. The ability to connect individuals and organizations at long distances, but who share interests, values, goals or common positions, led to bringing them into entities, have begun to play a significant role in international relations. Of course, many of them have had a short existence, but in some cases, practical effects remained (e.g. campaign to ban antipersonnel mines).

The tool that states have at their disposal to influence the behaviour of states non-state actors is public diplomacy. Of course, public diplomacy can be seen as an evolution of propaganda or psychological warfare during the World Wars, the Cold War and the War on Terror, a view shared especially in Anglo-Saxon space. But there is another genealogy of public diplomacy, in which it is part of the new diplomacy of Knowledge Society. 

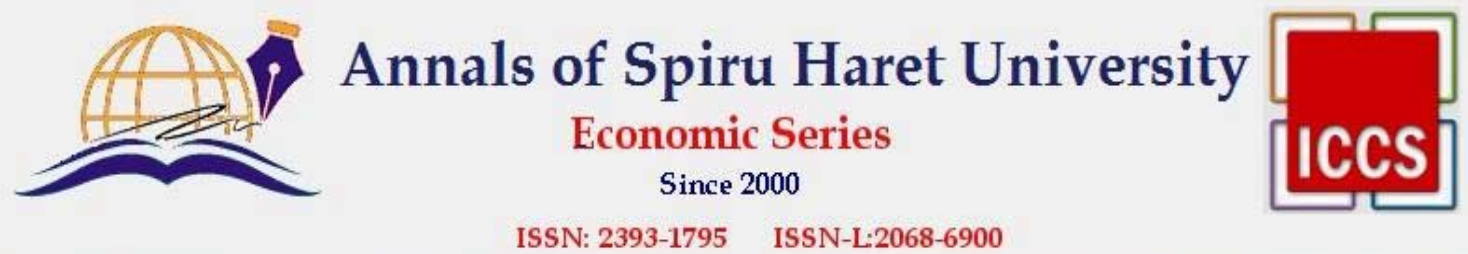

Issue 2/2016

We can say that public diplomacy began its existence during the First World War, when the US government created the Committee on Public Information, designed to develop support to the country entered the war by public opinion in the United States, but also to inform and influence foreign audiences about the US military effort to achieve democratic goals. The emergence of public diplomacy coincided with the explosive growth of modern mass media (cinema, radio, television, etc.) and reached a climax with World War II and the Cold War. These phenomena have led to the one of the most important research topics in communication studies.

Public diplomacy includes government programs in the fields of culture, science, education and information of citizens and the production of programs used to promote a country's national interest by informing and influencing foreign audiences. But public diplomacy requires more than that, regarding what we previously called the "soft" power. Unlike classical diplomacy, defined as the instrument by which heads of state or the government communicated at the highest levels, public diplomacy focuses on ways in which a country (or a multilateral organization like the United Nations), acting consciously or unconsciously, on individuals or institutions through formal or informal, directs communication with the citizens of another country. But like classical diplomacy, public diplomacy assumes that dialogue, rather than a presentation with advertising, it is essential to achieve foreign policy goals.

Therefore, to be effective, communication should be bi-directional, involving not only shaping messages that country transmits abroad, and analysis of how the message is interpreted by different companies and develop tools for listening and persuasion.

\section{References}

1. Bator, Jozef, Public Diplomacy in Small and Medium-Sized Countries: Norway and Canada (Editura Oxford, 2008).

2. Bogdan, Alexandru T. and Comsa, Dana, Eco-Bio-Diplomacy (Bucharest: Academy of Scientists in Romania Publishing House, 2011).

3. Bogdan, Alexandru T. et al., "Prospects of Agrifood Green Power Forecasting for 2050 and 2100 with Sustainable Solutions Based on Ecobioeconomics New 

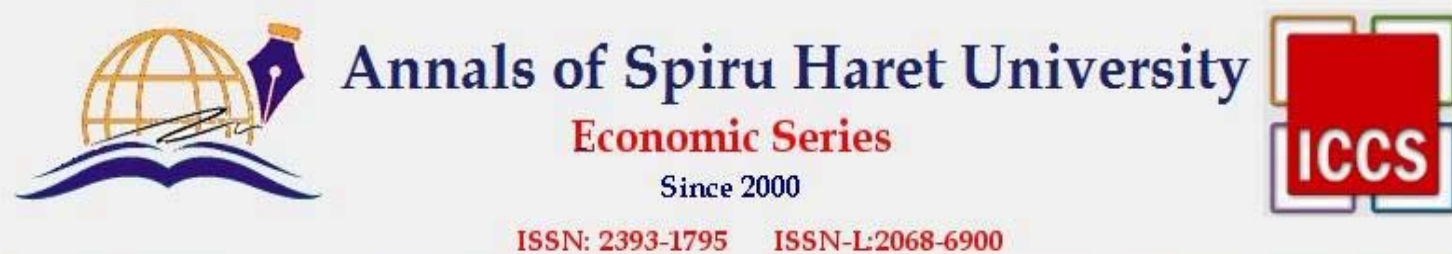

Issue 2/2016

Paradigm", UASVM Bulletin of Animal Science and Biotechnologies, (Bucharest: $67(1-2) / 2010)$.

4. Bolewski, W., "Diplomacy and International Relations Law in a Globalized Era", Springer Berlin Heidelberg (New York: 2003), 25-26.

5. Cull, Nicholas J., "Public Diplomacy: Lessons from the Past", CPD Perspectives on Public Diplomacy, (Cambridge: Polity Press, 2009).

6. Cull, Nicholas J., Public Diplomacy before Gullion: The Evolution of a Phrase. US Centre on Public Diplomacy (2014).

7. Dizard Jr, Wilson, Digital Diplomacy: U.S. Foreign Policy in the Information Age (New York: Praeger, 2001), 5-7.

8. Grant, R., The Democratisation of Diplomacy: Negotiating with the Internet (Oxford Internet Institute, Research Report: 2004, No. 5).

9. Guceac, I. and Porcescu, S., "Diplomația public - componentă indispensabilă a discursului extern în condițiile globalizării”, Akademos (nr. 1(6), martie, 2010).

10. Gurgu, Elena and Zorzoliu, Raluca, Advocacy in Romanian Public Policy, Procedia of Economics and Business Administration - PEBA 2015 (București: Editura Fundației România de Mâine, 2015).

11. Leonard, Mark et al., British Public Diplomacy in the Age of Schisms (The Foreign Policy Centre, 2005).

12. Leonard, Mark, et al., Public Diplomacy (Foreign Policy Centre, June 17, 2002), 53.

13. Melissen, Jan, Wielding Soft Power: The New Public Diplomacy (The Hague: Netherlands Institute of International Relations "Clingendael", 2005).

14. Nye, Joseph S., "The Benefits of Soft Power", A Journal of Leadership (Spring 2004-4).

15. Nye, Joseph S., Soft Power: The Means to Success in World Politics (Public Affairs; New Edition - April 26, 2005), 72.

16. Ociepka, Beata and Rzniejska, Marta, Public Diplomacy and EU Enlargement: The Case of Poland (Poland: Penguin, 2010).

17. Pigman, Geoffrey Allen, Contemporary Diplomacy (Cambridge: Polity Press, 2010).

18. Plischke, Elmer cited in Langholtz, Harbey J. and Stout, Chris E., The Psychology of Diplomacy (Westport: Praeger Publishers, 2004).

19. Potter, Evan H., "Canada and the New Public Diplomacy", Diplomacy Discussion Paper (Canada: 2005).

20. Report of USA Commission on Public Diplomacy from 1991, www. publicdiplomacy.org/15.01.10. 


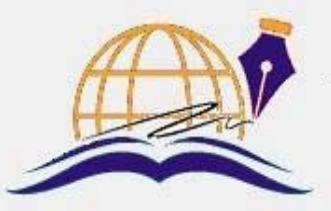

Annals of Spiru Haret University

Economic Series

Since 2000

ISSN: 2393-1795

ISSN-L:2068-6900

Issue 2/2016

21. Ross, Christopher, "Pillars of Public Diplomacy: Grappling with International Public Opinion", Harvard International Review (Vol. 25, 2003), http://www.harvardir.org/articles/1117/1/.

22. Tuch, Hans, Communicating with the world (New York: Public Affairs Publishing House, nr. 1(16), March 2010), 7.

23. Wolf, Charles Jr. and Rosen, Brian, Public Diplomacy. How to Improve It and Think About (Santa Monica, CA, Rand Corporation, 2004).

24. Манжулина Ольга, «Основы эффрективности», журнал «Стратегия России» (март, 2006). 
